obtained, and in particular $B$ melaninogenicus was found in two. In a recent survey of complications after sinus infections in children, Brook et al also found pathogenic anaerobes in every instance and Bacteroides spp in five of the eight cases. ${ }^{4}$

Penicillin is active against most anaerobes but some strains of $B$ melaninogenicus and most strains of $B$ fragilis are resistant. In addition, both of these strains have the capability to produce penicillinase, thus protecting penicillin sensitive organisms.

Bacteroides and anaerobic cocci have a greater tendency to induce septic thrombophlebitis than aerobes, ${ }^{5}$ and their presence is therefore likely to favour complications. This emphasises the role of early, detailed, and accurate bacteriological investigation in each case. Distinction of anaerobes from microaerophilic streptococci may be difficult and gas-liquid chromatography for volatile fatty acids is particularly relevant.

We suggest that unless anaerobes can be specifically excluded all paranasal sinus infections failing to respond promptly or developing complications should be treated with metronidazole in addition to the normal therapeutic regimen.

We thank Mr P D M Ellis, Mr D Moffat, and Mr D Hardy for permission to report these cases and Dr R E Warren for help in preparing this report.

1 De Louvois J, Gortvai P, Hurley R. Antibiotic treatment of abscesses of the central nervous system. Br Med $\mathcal{f}$ 1977;ii :985-7.

2 Brook I. Aerobic and anaerobic bacterial flora of normal maxillary sinuses. Laryngoscope $1981 ; 91: 372-6$.

${ }^{3}$ Lundberg C, Carenfelt C, Engquist S, Noro CE. Anaerobic bacteria in maxillary sinusitis. Scand $\mathcal{F}$ Infect Dis 1978;suppl 19:74-6.

${ }^{4}$ Brook I, Friedmann E, Rodriguez W, Controni G. Complications of sinusitis in children. Pediatrics $1980 ; 66$ :568-72.

${ }^{5}$ Willis A, Jones P, Reilly S. Management of anaerobic infections: prevention and treatment. Chichester: Research Studies Press (John Wiley \& Son Ltd), $1981: 6,42-3$.

(Accepted 17 November 1983)

Royal National Throat, Nose and Ear Hospital, London WC1X 8DA ANDREW GRACE, MB, BS, registrar

ADRIAN DRAKE-LEE, FRCS, senior registrar

Correspondence to: Dr Andrew Grace.

\section{Hypermagnesaemia and hypophosphataemia after ingestion of magnesium sulphate}

Hypermagnesaemia after ingestion of magnesium sulphate is rare in the absence of intestinal or renal disease. ${ }^{1}$ We report such a case in which the patient made an excellent recovery.

\section{Case report}

A woman aged 25, who had apparently been in good health previously, presented to hospital drowsy and hypothermic. She had been found naked and unconscious early that morning outside her home. Two empty $100 \mathrm{~g}$ bottles of magnesium sulphate (Epsom salts) were found beside her bed. On examination in intensive care she was hypothermic $\left(32^{\circ} \mathrm{C}\right.$ rectally) with considerable pallor and vasoconstriction. Her blood pressure was 120/80 $\mathrm{mm} \mathrm{Hg}$, heart rate 70 beats $/ \mathrm{min}$ and regular, and respiration adequate. She was drowsy, responding only slowly to spoken commands. Her pupils reacted sluggishly to light. Muscle tone was increased, but tendon reflexes were reduced. Focal neurological signs were absent and plantar reflexes equivocal. Electrocardiography showed sinus rhythm with J waves; this is consistent with hypothermia. Full toxicological screening did not detect ethanol or drugs.

Management consisted of gradual warming with blankets and rehydration with warmed intravenous fluids. Over the 24 hours after admission she received 3.51 of fluids containing sodium $140 \mathrm{mmol}(\mathrm{mEq})$, potassium 50 $\mathrm{mmol}(\mathrm{mEq})$, and calcium $15 \mathrm{mmol}(601 \mathrm{mg})$. No phosphate was given. She was alert and orientated and her temperature had returned to normal within eight hours; she was transferred to a general ward the next day.

On admission plasma analysis showed potassium concentration $2 \cdot 8$ mmol/l, urea concentration $3.7 \mathrm{mmol} / 1(22 \mathrm{mg} / 100 \mathrm{ml})$, and creatinine concentration $80 \mu \mathrm{mol} / 1(1.0 \mathrm{mg} / 100 \mathrm{ml})$. The table shows plasma magnesium, calcium, albumin, and phosphate concentrations. Haemoglobin concentration was $17 \cdot 1 \mathrm{~g} / \mathrm{dl}$ and packed cell volume $0 \cdot 52$. Plasma sodium, urea, and creatinine concentrations changed little during the 24 hour period. A spot sample of urine obtained two hours after admission showed magnesium concentra-
Changes in plasma concentrations during treatment

\begin{tabular}{|c|c|c|c|c|c|c|}
\hline & \multirow[b]{2}{*}{$\begin{array}{c}\text { Reference } \\
\text { range }\end{array}$} & \multicolumn{5}{|c|}{ Hours after admission } \\
\hline & & 0 & $\begin{array}{c}2 \mathrm{~h} \\
35 \mathrm{~min}\end{array}$ & $\begin{array}{c}5 \mathrm{~h} \\
15 \mathrm{~min}\end{array}$ & $\begin{array}{l}12 \mathrm{~h} \\
40 \mathrm{~min}\end{array}$ & $\begin{array}{c}22 \mathrm{~h} \\
15 \mathrm{~min}\end{array}$ \\
\hline $\begin{array}{l}\text { Magnesium (mmol/1) } \\
\text { Calcium (mmol/l) } \\
\text { Albumin (g/l) }\end{array}$ & $\begin{array}{c}0 \cdot 7-1 \cdot 1 \\
2 \cdot 25-2 \cdot 65 \\
35-45\end{array}$ & $\begin{array}{c}7 \cdot 9 \\
2 \cdot 47 \\
49\end{array}$ & $\begin{array}{l}4 \cdot 7 \\
2 \cdot 07 \\
47\end{array}$ & $\begin{array}{r}2 \cdot 50 \\
1 \cdot 76 \\
41\end{array}$ & $\begin{array}{l}1 \cdot 18 \\
2 \cdot 02 \\
37\end{array}$ & $\begin{array}{l}0 \cdot 75 \\
2 \cdot 26 \\
36\end{array}$ \\
\hline $\begin{array}{l}\text { Inorganic phosphate } \\
(\mathrm{mmol} / \mathrm{l})\end{array}$ & $0 \cdot 8-1 \cdot 4$ & 0.39 & $0 \cdot 20$ & 0.75 & 1.07 & $1 \cdot 26$ \\
\hline
\end{tabular}

Conversion: SI to traditional units-Magnesium: $1 \mathrm{mmol} / 1 \approx 2.4 \mathrm{mg} / 100 \mathrm{ml}$. Calcium: $1 \mathrm{mmol} / 1 \approx 4 \mathrm{mg} / 100 \mathrm{ml}$. Inorganic phosphate: $1 \mathrm{mmol} / 1 \approx 3 \cdot 1 \mathrm{mg} / 100 \mathrm{ml}$.

tion $908 \mathrm{mmol} / 1(2210 \mathrm{mg} / 100 \mathrm{ml})$, calcium concentration $16.3 \mathrm{mmol} / 1$ $(65.2 \mathrm{mg} / 100 \mathrm{ml})$, inorganic phosphate concentration $1.0 \mathrm{mmol} / 1(3.1 \mathrm{mg} /$ $100 \mathrm{ml}$ ), and osmolality $1300 \mathrm{mmol}(\mathrm{mosmol}) / \mathrm{kg}$ water.

\section{Comment}

Our patient had presumably taken an overdose of magnesium sulphate. Despite a considerably increased plasma magnesium concentration on admission the cardiovascular effects of hypermagnesaemianamely, hypotension, electrocardiographic changes, and heart blockwere absent. ${ }^{1}$ Normal renal function permitted rapid urinary excretion of magnesium, making an uneventful recovery possible.

Interestingly, the plasma calcium concentration decreased by 0.71 $\mathrm{mmol} / 1(2.8 \mathrm{mg} / 100 \mathrm{ml})$ in the first five and a quarter hours after admission with only a small part of this decrease $(0.16 \mathrm{mmol} / 1(0.6$ $\mathrm{mg} / 100 \mathrm{ml}$ )) being attributable to a concomitant decrease in albumin concentration. Plasma calcium concentration fell despite administration of calcium. Plasma inorganic phosphate concentration also fell initially, reaching a minimum of $0.20 \mathrm{mmol} / 1(0.6 \mathrm{mg} / 100 \mathrm{ml})$ after two and a half hours. The reason for the initial low plasma concentration of inorganic phosphate is not clear. Possibly the sparingly soluble magnesium phosphate was precipitated in tissues. Between two hours 35 minutes and five hours 15 minutes after admission the plasma inorganic phosphate concentration increased by $0.55 \mathrm{mmol} / 1$ ( 1.7 $\mathrm{mg} / 100 \mathrm{ml}$ ) even though no phosphate was given.

Hypermagnesaemia may cause hypocalcaemia. This effect may possibly be mediated by decreased secretion of parathyroid hormone ${ }^{2}$ and responsiveness of end organs. ${ }^{3}$ An effect of hypermagnesaemia on plasma concentrations of inorganic phosphate has not, however, been described before. The increase in plasma inorganic phosphate concentration from a minimum of $0.2 \mathrm{mmol} / 1(0.6 \mathrm{mg} / 100 \mathrm{ml})$ may be explained by two mechanisms. Firstly, decreased parathyroid hormone activity would increase renal tubular absorption and reduce urinary excretion of phosphate. The low phosphate concentration in the spot sample of urine supported this possibility. Secondly, phosphate may have become mobilised from the precipitated magnesium phosphate as plasma magnesium concentrations fell rapidly to normal.

Our patient had severe hypermagnesaemia resulting presumably from ingestion of magnesium sulphate. Respiratory and cardiovascular complications were absent. The changes in plasma calcium and phosphate concentrations seen in this patient provide further evidence for the sugggestion that hypermagnesaemia causes decreased parathyroid hormone activity.

1 Mordes JP, Wacker WEC. Excess magnesium. Pharmacol Rev 1977;29: 273-300.

2 Massry SG, Coburn JW, Kleeman CR. Evidence for suppression of parathyroid gland activity by hypermagnesemia. $\mathcal{f}$ Clin Invest 1970;49:161929.

${ }^{3}$ Slatopolsky E, Mercado A, Morrison A, Yates J, Klahr S. Inhibitory effects of hypermagnesemia on the renal action of parathyroid hormone. $\mathcal{f C l i n}$ Invest 1976;58:1273-9.

(Accepted 10 November 1983)

Department of Clinical Biochemistry, University of Western Australia, Perth, Australia 6009

P GARCIA-WEBB, MD, FRCPA, senior lecturer

C BHAGAT, MD, FRCPA, senior registrar

Intensive Care Unit, Sir Charles Gairdner Hospital, Perth, Australia 6009

T OH, FFARCS, FFARACS, director

G HART, MB, BS, registrar

W THOMPSON, MB, FFARACS, staff specialist

Correspondence to : Dr P Garcia-Webb. 